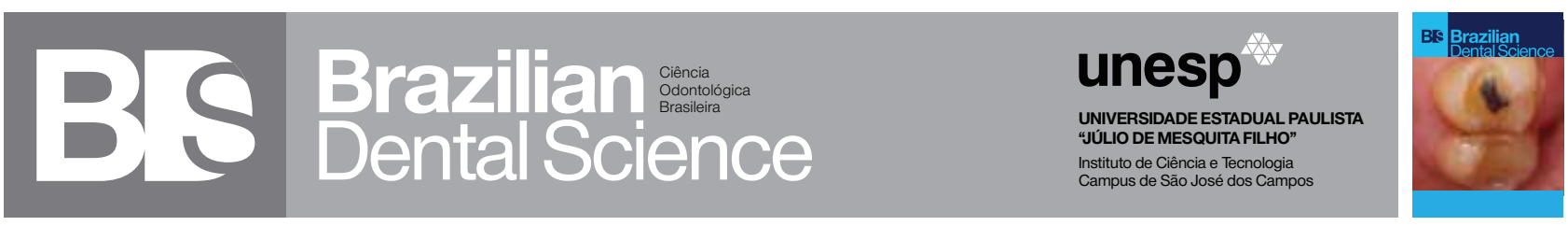

\title{
Influence of dentin abrasion methods on the bond strength of self-etching adhesive systems
}

Influência de métodos de abrasão da dentina na resistência de união de sistemas adesivos autocondicionantes.

Patrícia Itocazo ROCHA ${ }^{1}$, Rayssa Ferreira ZANATTA ${ }^{1}$, Clovis PAGANI ${ }^{1}$, José Roberto RODRIGUES ${ }^{1}$, Alessandra Buhler BORGES ${ }^{1}$

1 - Institute of Science and Technology, UNESP - Univ Estadual Paulista, São José dos Campos (SP) - School of Dentistry - Department of Restorative Dentistry - São José dos campos - SP - Brazil.

\begin{abstract}
Objective: The aim of this study was to compare the bond strength of two self-etching adhesive systems with different types of dentin abrasion. Methods: Thirty two sound human molars were selected and had the dentin surface exposed and flattened. Tooth were randomly divided into four experimental conditions, according with the adhesive system [Clearfil SE Bond (SE) and One-Up Bond $\mathrm{F}(\mathrm{ONE})$ ] and the type of dentin abrasion [conventional diamond bur (D) and ultrasound diamond bur (CVD)]. The adhesives were applied following manufactures' instructions and light cured composite blocks of $4 \mathrm{~mm}$ height were placed over dentin. After storage in distilled water for $24 \mathrm{~h}$ in $37^{\circ} \mathrm{C}$, serial cuts were made on mesio-distal and buccal-lingual direction, obtaining specimens with stick format, with cross section of $8 \mathrm{~mm}^{2}$. The microtensile test was performed at a crosshead speed of $0.5 \mathrm{~mm} / \mathrm{min}$ and load cell of $10 \mathrm{~kg}$, until failure. Data were submitted to ANOVA-2-Way followed by Tukey test (5\%). Results: The results (MPa) were: D/ SE: $24.06 \pm 8.84$, D/ONE: $15.03 \pm 8.61$, CVD/SE: $39.90 \pm 8.24$ and CVD/ONE:15.03 \pm 8.61 . It can be concluded that the adhesive system Clearfil SE Bond showed higher bond strength related with the abrasion with CVD; the type of dentin abrasion interfered on the performance of Clearfil SE Bond but did not influence the One-Up Bond F results.
\end{abstract}

\section{KEYWORDS}

Self-etching adhesive systems; Bond strength; Dentin.

\section{RESUMO}

Objetivo: O objetivo desta pesquisa foi comparar a resistência de união de dois sistemas adesivos autocondicionantes com diferentes métodos de preparo da dentina. Métodos: Foram utilizados 32 molares humanos hígidos extraídos, sendo que a superfície dentinária oclusal foi exposta e planificada. Os dentes foram aleatoriamente divididos em quatro diferentes condições experimentais de acordo com o sistema adesivo: Clearfil SE Bond (SE) ou OneUp Bond F (ONE) e com o método de preparo da dentina: ponta diamantada em alta rotação (D) ou ponta diamantada em ultra-som (CVD). Os adesivos foram aplicados de acordo com as recomendações do fabricante e foram confeccionados blocos de $5 \mathrm{~mm}$ de altura de resina composta fotopolimerizável, pela técnica incremental. Após estocagem em água destilada por $24 \mathrm{~h}$ a $37^{\circ} \mathrm{C}$, foram realizadas secções seriadas no sentido mésio-distal e vestíbulo-lingual, obtendo-se espécimes em forma de palitos, com secção transversal de aproximadamente $0.8 \mathrm{~mm} 2$. Os corpos-de-prova foram submetidos ao ensaio de microtração com velocidade de $0.5 \mathrm{~mm} / \mathrm{min}$ e célula de carga de $10 \mathrm{~kg}$. Os dados foram submetidos à análise estatística ANOVA e teste de Tukey (5\%). Resultados: Os resultados (MPa) foram: D/SE: $24,06 \pm 8,84$, D/ONE: 15,03 $\pm 8,61, \mathrm{CVD} / \mathrm{SE}:$ $39,90 \pm 8,24$ e CVD/ONE:15,03 $\pm 8,61$. Concluiuse que o sistema adesivo Clearfil SE Bond apresentou superioridade significativa de resistência de união em relação ao preparo com ponta CVD; o método de preparo da dentina interferiu no desempenho do Clearfil SE Bond e não influenciou o desempenho do One-Up Bond F.

\section{PALAVRAS-CHAVE}

Sistemas adesivos autocondicionantes; Resistência à tração; Dentina. 


\section{INTRODUCTION}

The adhesive concept opened a variety
of new possibilities for Restorative Dentistry, allowing the reestablishment of form, function and aesthetics of dental tissues lost by pathologies or traumatisms. Investments in studies that investigate the performance of restorative materials and techniques have been widely stimulated, with the purpose to provide scientifically basis for clinical application and the development of new techniques and modern materials. Considering the morphologic and functional differences between enamel and dentin structures, the adhesion of dental material to dentin substrate is still considered a great challenge to researchers [1].

The smear layer is a coating of cutting debris that forms over dentin when it is instrumented, and contains a varying amount of saliva, bacteria and tiny particles of dental tissue. The instrument used during the cavity preparation determines the morphology and characteristics of the smear layer, whereas its thickness is determined by the presence or absence of water during the use of rotatory instruments and the dentin region, which can presents different proportions of organic and inorganic tissues [2].

The CVDentus diamond burs are fabricated from a known technology of chemical vapor deposition, presenting high cut efficacy and the possibility to be attached to an ultrasonic equipment, which may result in changes during the formation of smear layer over the dental tissue $[3,4]$.

The hybrid layer is a tridimensional net between the polymer and the collagen, formed when the adhesive soaks the collagen fibers of the previously etched dentin, however this net may not promote a continuous and stable bonding between the resin and the dentin substrate [5].

Over-etching dentin causes a profound demineralization of this dental tissue, such that the monomers cannot be properly infiltrated, creating regions with exposed collagen fibers (not hybridized) that is susceptible to hydrolysis [6]. After the stages of etch, wash and dry the dentin, the maintenance of humidity in this dental structure is a very critical step, especially because its a very subjective concept, being both the excess of humidity and dryness, harmful for the quality of dentin hybridization.

Considering that the smear layer promotes the sealing of dentin surface and reduces its permeability, studies have being developed to verify the relation between the type of instruments used on dentin tissue and the performance of the self-etching adhesives, once these materials can melt, modify or incorporate to the debris layer during their application [5,7]. The trend of development of new adhesive systems with simple application has introduced to the market the self-etching systems with one step, also known as all-inone, which combines the conditioning agents, primer and adhesive in one bottle [8].

Thus, this study aims to evaluate the bond strength of two self-etching adhesives to human dentin, considering the following: a) self-etching adhesive system of two steps - self-etching primer; b) self-etching adhesive system of one step - self-etching adhesive; c) dentin abrasion with diamond bur; d) dentin abrasion with CVD bur and ultrasound. The null hypotheses tested are: a) the type of dentin abrasion does not influence the selfetching adhesives bond strength; b) there is no difference between the two adhesive systems tested.

\section{MATERIALS AND METHODS}

This study has been approved by the Ethics Committee of Dentistry School of São José dos Campos - UNESP - SP, by protocol number 010/2005-PH/CEP.

Thirty two sound human third molars extracted by orthodontic or surgical reasons were used. The enamel of the oclusal surface was removed using a water-cooled diamond disk in a low-speed diamond saw (Labcut 1010, Extec; Enfield, CT, USA). To certify that all enamel was removed, the flat surface obtained from all teeth was evaluated in optical microscope (Zeiss / Stemi 2000 C, Jena, Germany), with 30x magnification.

The teeth were randomly assigned into two groups, according with the type of dentin abrasion. This way, 16 teeth were prepared with cilindrical diamond bur (PD-882.314.012 
- Komet Group, Germany) set in dental turbine at high speed (Extra Torque 605 Turbine - Kavo Dental Co, Germany) with water irrigation. The surface was prepared by the same operator, who gently passed the burs across the dentin surface 30 times under copious air-water spray. The others 16 teeth had their dentinal surface prepared with the diamond CVD bur (CVDentus, São José dos Campos, SP, Brasil) associated with an ultrasound device Nac-Plus (modelo AE-200, Adiel Comercial Ltda.,Brasil) set in $30 \mathrm{kHz}$ frequency and $70 \%$ of the vibration potency, under water lubrication.

After dentin preparation, each group were randomly subdivided into two new ones, according to the adhesive system used, which were applied following the manufactures' recommendations (Table 1 ). Thereby the final groups were determined by the type of dentin abrasion and the adhesive systems: D/ SE (Clearfil SE Bond); D/ONE (One-Up Bond F); CVD/SE (Clearfil SE Bond) and CVD/ONE (One-Up Bond F).

Table 1 - Procedures for adhesive system application

\begin{tabular}{|c|c|}
\hline Material & Procedure \\
\hline \multirow{5}{*}{$\begin{array}{l}\text { Clearfil } \\
\text { SEBond }\end{array}$} & $\begin{array}{l}\text { 1. Quick blast of air followed by primer } \\
\text { application in dentin surface }\end{array}$ \\
\hline & 2. Wait of $20 \mathrm{~s}$ \\
\hline & 3. Adhesive application \\
\hline & 4. Quick blast of air \\
\hline & 5. Light cure for $10 \mathrm{~s}$ \\
\hline \multirow{5}{*}{$\begin{array}{l}\text { One-Up } \\
\text { BondF }\end{array}$} & 1. Quick blast of air \\
\hline & $\begin{array}{l}\text { 2. Mix of agent } A \text { and agent } B \text { until obtaining a } \\
\text { homogeneous rosaceous mixture. }\end{array}$ \\
\hline & $\begin{array}{l}\text { 3. Application of the mixture in the dentinal } \\
\text { surface }\end{array}$ \\
\hline & 4. Wait of $20 \mathrm{~s}$ \\
\hline & 5. Light cure for $10 \mathrm{~s}$ \\
\hline
\end{tabular}

Both adhesive systems were light cured with Curing Light XL 300 (3M-ESPE, St Paul, MN, USA) with light intensity of $600 \mathrm{~mW} / \mathrm{cm}^{2}$. Then, over the oclusal portion, composite blocks of TPH - Spectrum (Dentsply Caulk, Illinois, USA) where placed in four increments of 1 $\mathrm{mm}$ height each. Every block was light cured for $40 \mathrm{~s}$. After the composite block confection, the specimens were immersed in distilled water and stored at $37^{\circ} \mathrm{C}$ for $24 \mathrm{~h}$.

The specimens were adapted in a serial cut machine, and using a flexible diamond disc (Komet Group GmbH, Besigheim, Germany) in low speed rotation, parallel cuts were made following teeth long axis, with $0.8 \mathrm{~mm}^{2}$ thickness, on mesio-distal and buccal-lingual direction. Another cut in the cervical portion was made in order to obtain the stick samples for microtensile test.

To evaluate the microtensile bond strength, each sample has its extremities glued with cyanoacrylate adhesive to a modified rule caliper, in a way that the adhesive interface was positioned perpendicular to the load application (Figure 1). The set (rule caliper and sample) were fixed on a universal testing machine (EMIC-L-1000, São José dos Pinhais, Brazil) and submitted to a tensile load with velocity of $0.5 \mathrm{~mm} / \mathrm{min}$ and load cell of $10 \mathrm{~kg}$, until failure.

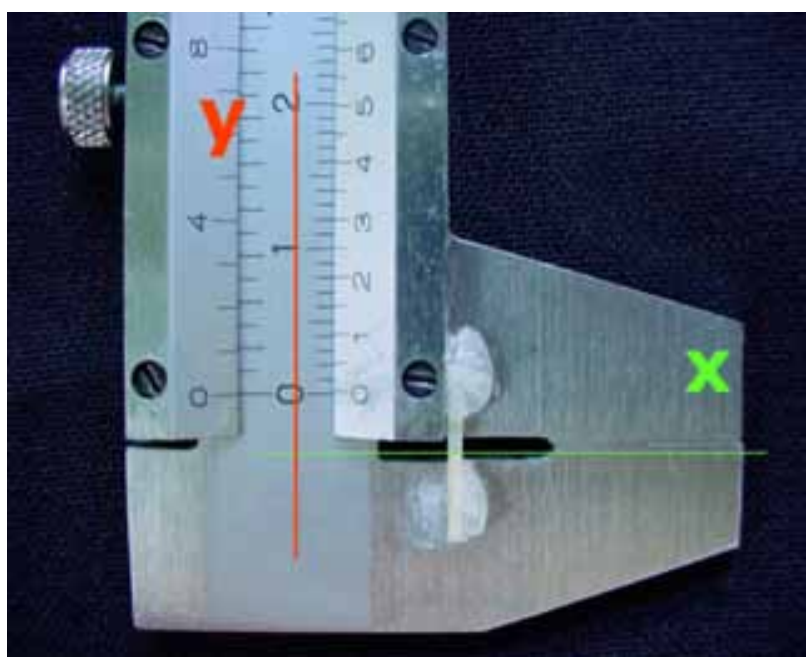

Figure 1- Image of device used for specimen fixation during the microtensile test (modified caliper). 
After the test, both fractured portions were removed from the set and the fracture area was measured with a digital caliper rule with 0.01 $\mathrm{mm}$ of resolution (Starret, Mod. 272, Itu, Brazil). The adhesive area value was transformed to $\mathrm{cm}$ and the value of load in $\mathrm{kg}$. The final values of bond strength were calculated and expressed in MPa. Data were submitted to statistical analysis with ANOVA two factors. The statistical analysis was made to verify the hypothesis of nonsimilarity between the bond strength and the four variables.

\section{RESULTS}

Data were submitted to a variance analysis in two factor, and statistical analysis showed difference for the factors adhesive type $(p=0.001)$ and dentin abrasion type ( $p=0.0027)$, as well as for the interaction factor $(\mathrm{p}=0.0389)$.

Related to interaction, it can be seen that for the adhesive Clearfil SE Bond, the increase of bond strength achieved by the use of the CVD bur compared with the conventional diamond bur (24.06 to $39.90 \mathrm{MPa}$ ) is higher than the increase od bond strength achieved with the use of One-Up Bond F (15.03 a 18.28 MPa).

Considering the adhesive performance, Clearfil SE Bond (SE) had better results (31.98 $\pm 11.62 \mathrm{MPa})$ than One-Up Bond F (16.65 \pm $7.78 \mathrm{MPa}$ ), without taking in account the type of dentin abrasion.

Regarding the interference about the dentin abrasion type, it can be verified that the CVD bur achieved higher values of bond strength $(29.09 \pm 13.39 \mathrm{MPa})$ than the conventional diamond bur (19.54 $\pm 9.63 \mathrm{MPa})$ in high speed, disregarding the adhesive system used.

When the mean values of the conditioning experiments are compared, by the multiple comparisons Tukey test (5\%), two sets of same performance are established (Table 2).
It's verified that the experimental condition Clearfil SE Bond (SE) with CVD bur and ultrasound (CVD) shows the better bond strength performance of the adhesive system with dentin surface.

\section{DISCUSSION}

The first null hypothesis was rejected, once the type of dentin abrasion partially interfered on the self-etching adhesive systems performance, as described in previous studies [7, 9, 10]. Since the smear layer affects the bond between the adhesive systems and the prepared dentin, factors like the type of instrument used, size of the abrasive and the speed of abrasion, should be considered as parameters that affects the adhesion [11]. The bond strength was affected by the dentin abrasion surface method when Clearfil SE Bond was applied over the dentin prepared with CVD bur, compared with the conventional diamond bur in high speed. This fact could be associated with the difference in the smear layer thickness formed with different methods. It was previously demonstrated that cavity walls prepared with conventional diamond burs presented a ticker smear layer and a blocked entrance of dentin tubules, while in cavity walls prepared with the CVD bur with ultrasound, most of the dentin tubules were unobstructed and some regions did not show smear layer $[3,4,12]$. This minor portion of smear layer is a characteristic of the ultrasound equipment, which uses a turbulent water fluid during the ultrasonic vibrations, capable to act in the clearance of the smear layer and smear plugs when the CVDentus bur is used [12].

The self-etching primer was developed to incorporate the smear layer to the hybrid layer. However, the buffer capacity of the smear layer can neutralize part of the acidic potential of this primer, compromising the penetration of the adhesive system in the subjacent dentin [10].

Table 2 - Homogeneous groups, after Tukey test of multiple comparisons (5\%)

\begin{tabular}{cccc} 
Adhesive System & Dentin Abrasion & Mean (MPa) & Homogenous Groups \\
\hline Clearfil SEBond & CVD & 39.90 & A \\
\hline Clearfil SEBond & PD & 24.06 & WB \\
\hline One-Up BondF & CVD & 18.28 & B \\
\hline One-UpBondF & PD & 15.02 & B \\
\hline
\end{tabular}


This variable behavior of the Clearfil SE Bond adhesive when applied in different smear layer thickness was also observed by Ogata et al (2001) [7], who demonstrated that the bond strength obtained with conventional diamond burs was significantly lower than the one obtained with carbide burs or silicon carbide sandpaper, once these provides a thinner smear layer [7]. In fact, the bond strength is reduced in mean aggressively systems when the prepared dentin substrate (with smear layer) was compared to the fractured one (without smear layer) [13]. A previous study investigated the dentin surface treated with abrasive systems with different levels of aggressiveness in transmission electron microscopy and showed that the self-etching systems of mean aggressiveness, like the Clearfil SE Bond, did not completely remove the smear layer when the dentin was prepared with a diamond bur. However, a thin hybrid layer was formed, with presence of residual hydroxyapatite all over its extension, being available for chemical interaction with the adhesive material and showing satisfactory bond strength [14].

The self-etching adhesive One-Up Bond $F$ shows a combined system where the acid component, the primer and the adhesive are applied on a single step in dentin substrate, with $\mathrm{pH}$ of 1.3 [5]. The bond strength values found in this study for the One-Up Bond F adhesive were not affected by the type of dentin abrasion and showed similar values than the obtained by Tani \& Finger (2002) which demonstrated that the bond strength of selfetching adhesives of single step with high ionic potential, does not depend of the smear layer thickness in the substrate [9]. This property can be related with the adhesive $\mathrm{pH}$, which promotes the dissolution of the smear layer and the demineralization of the subjacent dentin. Studies using scanning electron microscopy showed that the hybrid layer formed by the One-Up Bond F, although thin (1-2 um), was more defined than the one formed by Clearfil SE Bond, and also with more tags. It was also found that the One-Up Bond F provides a higher level of dentin demineralization compared with Clearfil SE Bond, due to its ionic potential [5].

However, considering only the adhesive factor, the results of this study showed that the Clearfil SE Bond had a better adhesive performance compared with One-Up Bond F, rejecting the second hypothesis of similarity, as previously observed [15].

Tay \& Pashley (2001) [10], observed by transmission electron microscopy the hybrid layer of self-etching adhesive systems and classified then in: mild, like the Clearfil SE Bond, with hybrid layer between 0.4 and $0.5 \mathrm{um}$ thickness, with the presence of smear layer and smear plugs, both hybridized; moderate, where it was observed the complete dissolution of the smear layer and smear plugs, but hybridized, with hybrid layer with 1.2 to $2.2 \mathrm{um}$; and, aggressive, where the smear layer and smear plugs were completely solubilized, presenting a hybrid layer with 2.5 to $5.0 \mathrm{um}$. The authors observed that the use of aggressive adhesive systems favors a demineralization pattern similar to the pattern of the conventional adhesive systems and that the thickness of the hybrid layer is not related with the bond strength [16]. It has being previously demonstrated that the interaction of the self-etching adhesive systems with dentin varies with their $\mathrm{pH}$ (aggressiveness level), and with the type of dentin abrasion [14].

To study the physical-chemical interactions and interfaces between self-etching adhesives and dentin, Wang \& Spencer (2004), submitted specimens to scanning electron microscopy and observed regions of demineralized dentin but without presence of monomers, in the allin-one systems [17]. This is believed to occur because of the water presence on the single step self-etching adhesives formula, preventing the complete polymerization of the monomer and compromising the quality of the adhesive interface. On the other hand, this was not evident on the two-step self-etching adhesive system, what could explain its better performance on the bond strength tests; even presenting a lower aggressiveness (higher $\mathrm{pH}$ ).

Indeed, the scanning electron microscopy observation of the dentin/adhesive system interface of the Clearfil SE Bond showed a homogenous hybrid layer [[18]. This way, it is suggested that the bond strength is associated with the quality (homogeneity) of the hybrid layer and not only by its quantity (thickness). 
The discrepancy between demineralization depth and the monomer infiltration should not occur with self-etching adhesives, but nanoinfiltration have being verified and assigned to the incompletely water removal of these adhesives. This fact is related with the self-etching material. The hydrophilic and hydrophobic monomers present in the single step adhesives increases nanoinfiltration. The hydrolysis of acid monomers in self-etching adhesives of single step can result in the formation of polyethylene glycol, methacrylic acid and trimellitic acid. These acids are not light cured and can continue to etch dentin after the hybrid layer formation. So, the concept of conditioning and simultaneously infiltrating is not associated to all the self-etching adhesives, whereas the formulation and ionic potential can be related with the presence of a zone of demineralized dentin, but without monomer infiltration, below the hybrid layer $[19,20]$.

The CVD bur can improve the performance of some self-etching adhesive systems, depending on its formulation and bond mechanism. However its fundamental to consider that, despite all the advantages present by the CVD system associated with ultrasound, like durability, decrease of the noise levels and increase of patient comfort $[3,4]$, there's still some limitations regarding its clinical use, when compared with the conventional diamond bur. The self-etching adhesives present a higher simplicity of use, and, theoretically, advantages related with the quality of the hybrid layer formed. However, it should be carefully used and the professionals should be aware of the bond mechanism of these materials, which varies with formulation and ionic potential.

\section{CONCLUSION}

According with the proposed methodology, it can be concluded that the adhesive system Clearfil SE Bond showed higher bond strength values than did One-Up Bond F, independently of the bur type used; the dentin prepared with CVD bur showed statistically higher values of bond strength compared with the conventional diamond bur when Clearfil SE Bond was used; and, the performance of One-Up Bond F was similar for both types of dentin abrasion methods (conventional and CVDentus) tested.

\section{REFERENCES}

1. Spencer P, Ye Q, Park J, Misra A, Bohaty BS, Singh V, et al. Durable Bonds at the Adhesive/Dentin Interface: An Impossible Mission or Simply a Moving Target? Brazi Dent Sci. 2012;15(1):4-18.

2. Joynt RB, Davis EL, Wieczkowski G, Jr., Yu XY. Dentin bonding agents and the smear layer. Operative dentistry. 1991;16(5):186-91.

3. de Oliveira MT, de Freitas PM, de Paula Eduardo C, Ambrosano GM, Giannini M. Influence of Diamond Sono-Abrasion, Air-Abrasion and Er:YAG Laser Irradiation on Bonding of Different Adhesive Systems to Dentin. Eur J dent. 2007;1(3):158-66.

4. Vieira D, Vieira D. Pontas de diamante CVD: início do fim da altarotação? Dent Assoc-Brasil. 2002;Set-Out(5):307-11.

5. Wang Y, Spencer P. Hybridization efficiency of the adhesive/ dentin interface with wet bonding. Journal of dental research. 2003;82(2):141-5.

6. Tay FR, Carvalho RM, Yiu CK, King NM, Zhang Y, Agee K, et al. Mechanical disruption of dentin collagen fibrils during resin-dentin bond testing. The journal of adhesive dentistry. 2000;2(3):175-92.

7. Ogata M, Harada N, Yamaguchi S, Nakajima M, Pereira PN, Tagami J. Effects of different burs on dentin bond strengths of self-etching primer bonding systems. Operative dentistry. 2001;26(4):375-82.

8. Freedman $\mathrm{G}$, Leinfelder K. Seventh-generation adhesive systems. Dentistry today. 2002;21(11):106-11.

9. Tani C, Finger WJ. Effect of smear layer thickness on bond strength mediated by three all-in-one self-etching priming adhesives. $J$ adhesive dent. 2002;4(4):283-9.

10. Tay FR, Pashley DH. Aggressiveness of contemporary self-etching systems. I: Depth of penetration beyond dentin smear layers. Dent Mat. 2001;17(4):296-308.

11. Ermis RB, De Munck J, Cardoso MV, Coutinho E, Van Landuyt $\mathrm{KL}$, Poitevin A, et al. Bond strength of self-etch adhesives to dentin prepared with three different diamond burs. Dent Mat. 2008;24(7):978-85.

12. Cardoso MV, Coutinho E, Ermis RB, Poitevin A, Van Landuyt $K$ De Munck J, et al. Influence of dentin cavity surface finishing on micro-tensile bond strength of adhesives. Dent Mat. 2008;24(4):492-501.

13. Suyama Y, Luhrs AK, De Munck J, Mine A, Poitevin A, Yamada T, et al. Potential Smear Layer Interference with Bonding of Self-etching Adhesives to Dentin. J Adhesive Dent. 2013.

14. Sarr M, Kane AW, Vreven J, Mine A, Van Landuyt KL, Peumans M, et al. Microtensile bond strength and interfacial characterization of 11 contemporary adhesives bonded to bur-cut dentin. Oper dent. 2010;35(1):94-104.

15. Pucci CR, Araújo MAM. Estudo comparativo in vitro da resistência ao cisalhamento de sistemas adesivos em dentina humana: uso de hipoclorito de sódio em sistemas convencionais ou primers acidificados. Odonto (São Bernardo do Campo). 2005;13(26):12-22.

16. Phrukkanon S, Burrow MF, Tyas MJ. Effect of cross-sectional surface area on bond strengths between resin and dentin. Dent Mat. 1998;14(2):120-8.

17. Wang Y, Spencer P. Physicochemical interactions at the interfaces between self-etch adhesive systems and dentin. J Dent. 2004;Sep(32(7)):567-79. 
18. Doi J, Itota T, Torii Y, Nakabo S, Yoshiyama M. Micro-tensile bond strength of self-etching primer adhesive systems to human coronal carious dentin. J oral rehab. 2004;31(10):1023-8.

19. Yiu CK, King NM, Pashley DH, Suh BI, Carvalho RM, Carrilho MR, et al. Effect of resin hydrophilicity and water storage on resin strength. Biomaterials. 2004;25(26):5789-96.
20. Carvalho RM, Chersoni S, Frankenberger R, Pashley DH, Prati C, Tay FR. A challenge to the conventional wisdom that simultaneous etching and resin infiltration always occurs in self-etch adhesives. Biomaterials. 2005;26(9):1035-42.

\section{Rayssa Ferreira Zanatta}

(Corresponding address)

Avenida Engenheiro Francisco José Longo, 777,

Jardim São Dimas, São José dos Campos, SP,

Brazil, CEP: 12245-000

Date submitted: 2013 Jan 02

E-mail address: rayssa.ferreira@ict.unesp.br 